\title{
Diagnosis and Treatment of Paraneoplastic Neurological Disorders
}

\author{
R. Voltz ${ }^{\mathrm{a}}$ F. Graus ${ }^{\mathrm{b}}$ \\ ${ }^{a}$ Institute of Clinical Neuroimmunology and Department of Neurology, Klinikum Grosshadern, München, Germany

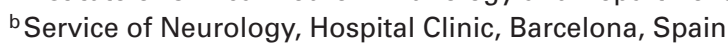

\section{Key Words}

Paraneoplastic syndromes · Neurological Disorders . Antibodies, anti-neuronal

\section{Abstract}

In about two thirds of cases, patients with paraneoplastic neurological disorders present to the neurologist without a known tumor. Due to the ongoing immune response, this tumor tends to stay biologically relatively benign, and therefore difficult to diagnose. In patients with a known tumor, the neurological symptoms often precede a tumor recurrence. In both scenarios, anti-neuronal antibodies are an invaluable diagnostic help to the clinician, and may be supplemented by other diagnostic tests such as MRI, CSF, and electrophysiology. Tumor therapy remains the mainstay of therapeutic options, although early immune therapy must be started in parallel. It is hoped that the recent fundamental advances in understanding the autoimmune pathology of these disorders, especially the role of cytotoxic T cells, will eventually lead to more effective treatment options.

\section{Diagnosis of a Paraneoplastic Neurological Syndrome}

Nearly any neurological syndrome (central, peripheral, neuromuscular, muscular) may be of paraneoplastic etiology $[1,2]$. Clinically it is of high therapeutic relevance to diagnose a paraneoplastic etiology quickly and correctly, as this will alter
Schlüsselwörter

Paraneoplastische Syndrome .

Neurologische Erkrankungen · Antikörper, anti-neuronale

\section{Zusammenfassung}

Etwa zwei Drittel der Patienten mit paraneoplastischen neurologischen Erkrankungen kommen zunächst zum Neurologen, da der Tumor nicht bekannt ist. Aufgrund der begleitenden Immunreaktion verhält sich dieser Tumor relativ gutartig, und ist daher auch relativ schwer zu diagnostizieren. Bei Patienten mit bereits bekanntem Tumor ist das Neuauftreten oder die Verschlechterung bestehender neurologischer Symptome immer ein Warnzeichen für ein Tumorrezidiv. In beiden Situationen ist das Vorliegen von anti-neuronalen Antikörpern diagnostisch sehr hilfreich, sie komplementieren andere diagnostische Maßnahmen wie MRT, Liquor- und Elektrophysiologie. Die Tumortherapie ist weiterhin die wichtigste therapeutische Maßnahme; eine begleitende Immuntherapie sollte parallel dazu eingeleitet werden. Die Fortschritte im Verständnis der autoimmunen Pathogenese dieser Syndrome, insbesondere die Rolle zytotoxischer T-Zellen, werden hoffentlich bald zu effektiveren Behandlungsmöglichkeiten führen.

the management of the patient dramatically. Either, in a patient without a known tumor, that tumor must be identified and treated, or in a patient with known tumor diagnosis, development of a paraneoplastic neurological syndrome frequently heralds tumor recurrence.

Initially, the term paraneoplastic neurological disorders

\begin{tabular}{ll}
\hline KARGER & @ 2004 S. Karger GmbH, Freiburg \\
Fax +49 7614520714 & Accessible online at: \\
$\begin{array}{l}\text { E-mail Information@Karger.de } \\
\text { www.karger.com }\end{array}$ & www.karger.com/onk
\end{tabular}

Prof. Dr. med. Raymond Voltz

Institut für Klinische Neuroimmunologie Klinikum Grosshadern

Marchioninistr. 15, D-81377 München

Tel. +49 89 7095-4439, Fax -7435

E-mail rvoltz@nro.med.uni-muenchen.de 
Table 1. Antibody-defined subgroups of paraneoplastic cerebellar degeneration

\begin{tabular}{|c|c|c|c|c|c|}
\hline Group & $\begin{array}{l}\text { Most frequent } \\
\text { tumors associated }\end{array}$ & Sex & Clinical symptoms & $\begin{array}{l}\text { Start of neurological } \\
\text { symtoms }\end{array}$ & Median survival \\
\hline Anti-Yo & breast, ovarian & $\mathrm{F}>>\mathrm{M}$ & subacute, severe & mostly before tumor diagnosis & $\begin{array}{l}100 \text { mo if breast, } \\
22 \text { mo if ovarian }\end{array}$ \\
\hline Anti-Hu & SCLC & $\mathrm{M}>\mathrm{F}$ & additional symptoms of PEM / SN & mostly before tumor diagnosis & 12 months \\
\hline $\begin{array}{l}\text { PCD and LEMS } \\
\text { (Ab neg.) }\end{array}$ & SCLC & $\mathrm{M}=\mathrm{F}$ & absent reflexes & mostly before tumor diagnosis & \\
\hline Anti-CRMP5/-CV2 & SCLC, thymoma & $\mathrm{F}>\mathrm{M}$ & $\begin{array}{l}\text { subacute, severe, additional symptoms } \\
\text { of PEM /SN }\end{array}$ & mostly before tumor diagnosis & \\
\hline Anti-Tr & Hodgkin's disease & $\mathrm{M}>\mathrm{F}$ & less severe, partly remitting & mostly after tumor diagnosis & \\
\hline Anti-Ri & breast & $\mathrm{F}$ & opsoclonus/ataxia & before or after tumor diagnosis & \\
\hline PCA-2 & lung & $\mathrm{M}=\mathrm{F}$ & additional symptoms of PEM / SN & mostly before tumor diagnosis & \\
\hline ANNA-3 & SCLC & & additional symptoms of PEM / SN & mostly before tumor diagnosis & \\
\hline Anti-Ma & various & $\mathrm{F}>\mathrm{M}$ & subacute, brainstem & mostly before tumor diagnosis & \\
\hline Atypical or no Ab & various & $\mathrm{F}=\mathrm{M}$ & various & before or after tumor diagnosis & \\
\hline
\end{tabular}

$\mathrm{Ab}=$ Antibody $; \mathrm{F}=$ female $; \mathrm{M}=$ male $; \mathrm{PCD}=$ paraneoplastic cerebellar degeneration; LEMS = Lambert-Eaton myasthenic syndrome; $\mathrm{PEM} / \mathrm{SN}$ = paraneoplastic encephalomyelitis / sensory neuropathy.

(PND) was coined for all non-metastatic neurological tumor complications where a specific etiology - such as vascular, infectious, metabolic, or treatment-related causes - could not be defined. Since the detection of the first antibody specific for a paraneoplastic etiology - the anti-Hu antibody - and description of its clinical relevance by Prof. Posner's laboratory the number of clinically relevant antibody reactivities as markers of a paraneoplastic etiology has grown at the speed of about one per year [1-3].

\section{Clinical Suspicion}

The first step in diagnosis relies on clinical skills leading to early clinical suspicion. Here, it has become clear in recent years that PND may not only follow the 'typical' subacute time course, but may also be indolent (over years!) or spontaneously relapsing-remitting (cave: misdiagnosis multiple sclerosis!) $[4,5]$. Furthermore, PND may present as a 'typical' neurological syndrome, such as LEMS (Lambert-Eaton myasthenic syndrome), cerebellar degeneration, or sensory neuronopathy, but it may also be 'atypical', presenting as depression or memory disturbance (as in limbic encephalitis) or pseudo-ileus (autonomic polyneuropathy) [6, 7].

\section{Limbic Encephalitis}

According to a recent large series of 50 patients, diagnostic criteria for a paraneoplastic limbic encephalitis (PLE) may be (1) typical clinical symptoms (see below), (2) less than 4 years to tumor diagnosis, (3) exclusion of other differential diagnoses and (4) pathological results in CSF, MRI or EEG [6]. Most patients have a subacute progressive course. Symptoms are short-term memory disturbance, epileptic seizures, acute confusional syndrome, further psychiatric symptoms (personality change, hallucination, depression), brainstem symptoms, signs of hypothalamic involvement, cognition disturbance, and signs of involvement of other neurological systems. In more than half of all patients, a tumor is diagnosed only after onset of symptoms. In $50 \%$ this was a lung tumor, $20 \%$ had a testicular tumor, and $8 \%$ a breast tumor. Three quarters of all tumors were growing only locally. All except one patient showed pathological results in two of three investigations: MRI, CSF, or measuring anti-neuronal antibodies [2, 8, 9].

\section{Cerebellar Degeneration}

A subacutely developing cerebellar syndrome in a woman above age 50 is in almost two thirds of cases a paraneoplastic cerebellar degeneration (PCD) [10]. Clinically, all patients with PCD present in a similar way. Using serological analysis of the associated anti-neuronal antibodies, the patients may be sudivided into several subgroups (table 1). These subgroups differ in the associated tumors, course (neurological stabilisation in anti-Yo, progression in anti-Hu), and regarding survival. Anti-Hu patients show a median survival of 9-12 months, anti-Yo patients with breast cancer 100 months and anti-Yo patients with other gynecological tumors 22 months $[8,11,12]$. In patients who have a SCLC associated with PCD, further diagnostic procedures should be performed to search for an associated Lambert-Eaton myasthenic syndrome (i.e. anti-VGCC and electrophysiology, see below) or the presence of VGCC even in absence of LEMS [13,14].

\section{Sensory Neuropathy}

The 'classical' paraneoplastic polyneuropathy is a sensory neuronopathy (SN) as first described by Denny-Brown in 1948 [15]. Typically, these patients initially have an asymmetrical and painful sensory neuropathy which evolves into typical complete loss of proprioception. The pseudo-athetotic movement of the hands and severe sensory ataxia is clinically impressive and usually very severe. Mostly, anti-Hu antibodies can be identified which have a specificity of $99 \%$ and a sensi- 
Table 2. Clinically useful antibody reactivities for identifying the paraneoplastic etiology of a given neurological syndrome

\begin{tabular}{|c|c|c|c|}
\hline \multirow{2}{*}{ Syndrome } & \multicolumn{2}{|l|}{ Antibody for } & \multirow[t]{2}{*}{ Associated tumor } \\
\hline & diagnosis & $\begin{array}{l}\text { paraneoplastic } \\
\text { etiology }\end{array}$ & \\
\hline LEMS & anti-VGCC & n.a. & SCLC \\
\hline \multirow{9}{*}{$\begin{array}{l}\text { Subacute cerebellar } \\
\text { degeneration }\end{array}$} & & anti-Hu & SCLC, prostate \\
\hline & & anti-PCA-2 & SCLC \\
\hline & & anti-CRMP5/-CV2 & SCLC, thymoma \\
\hline & & ANNA-3 & SCLC \\
\hline & & anti-Yo & ovary, breast \\
\hline & & anti-Ta/Ma2 & testis \\
\hline & & anti-Ma & miscellaneous \\
\hline & & anti-Ri & breast, lung \\
\hline & & anti-Tr & Hodgkin's lymphoma \\
\hline Opsoclonus/myoclonus (child) & & anti-Hu & neuroblastoma \\
\hline Dermatomyositis & & n.a. & ovary, lung, pancreas \\
\hline \multirow[t]{4}{*}{ Opsoclonus/myoclonus (adult) } & & anti-Ri & breast, lung \\
\hline & & anti-Hu & SCLC, prostate \\
\hline & & anti-Ma & miscellaneous \\
\hline & & anti-Ta/Ma2 & testis \\
\hline \multirow[t]{4}{*}{ Subacute sensory neuropathy } & & anti-Hu & SCLC, prostate \\
\hline & & anti-amphiphysin & SCLC \\
\hline & & ANNA-3 & SCLC \\
\hline & & anti-CRMP5/-CV2 & SCLC, thymoma \\
\hline \multirow[t]{4}{*}{ Limbic encephalopathy } & & anti-Hu & SCLC, prostate \\
\hline & & anti-Ta/Ma2 & testis \\
\hline & & ANNA-3 & SCLC \\
\hline & & anti-CRMP5/-CV2 & SCLC, thymoma \\
\hline \multirow[t]{4}{*}{ Extrapyramidal syndromes } & & anti-Hu & SCLC, prostate \\
\hline & & anti-Ta/Ma2 & testis \\
\hline & & anti-Ma & various \\
\hline & & anti-CRMP5/-CV2 & SCLC, thymoma \\
\hline Myasthenia gravis & $\begin{array}{l}\text { anti-AChR, } \\
\text { anti-MUSK }\end{array}$ & anti-titin & thymoma \\
\hline \multirow{3}{*}{$\begin{array}{l}\text { Sensorimotor } \\
\text { peripheral neuropathy }\end{array}$} & & anti-Hu & SCLC, prostate \\
\hline & & anti-amphiphysin & SCLC \\
\hline & & anti-CRMP5/-CV2 & SCLC, thymoma \\
\hline Encephalomyelitis & & anti-Hu & SCLC, prostate \\
\hline \multirow[t]{2}{*}{ Visual loss } & & anti-Hu & SCLC, prostate \\
\hline & & anti-recoverin & lung \\
\hline Stiff-person syndrome & anti-GAD & anti-amphiphysin & breast \\
\hline
\end{tabular}

n.a.: Not available; AChR: acetylcholine-receptor; GAD: glutaminic acid dehydrogenase; LEMS: Lambert-Eaton myasthenic syndrome; SCLC: small cell lung cancer; VGCC: voltage gated calcium channel. tivity of $82 \%$ for a paraneoplastic sensory neuropathy [16].

Other less frequent antibodies are anti-CV2 or anti-amphiphysin.

\section{Lambert-Eaton Myasthenic Syndrome (LEMS)}

In about $60 \%$ of patients with LEMS an underlying tumor, usually SCLC, rarely a lymphoma may be detected [17]. The associated SCLC have a significantly better prognosis if LEMS is present [18]. Unfortunately, no serological marker for the paraneoplastic etiology exists. Anti-VGCC antibodies are present in almost all patients with LEMS, and they do not differentiate between the paraneoplastic and non-paraneoplastic forms. The prevalence of LEMS in SCLC is about 3\% 
and must not be overlooked as LEMS responds well to immunomodulatory therapy [19-21].

\section{Anti-Neuronal Antibodies}

In case of clinical suspicion of the presence of a PND, antineuronal antibodies should be measured in the serum of the patient. Which antibodies should be looked for, depends on neurological syndrome (table 2 ). Here, only reactivities which are markers for the paraneopalstic etiology are mentioned. Antibodies such as anti-AChR, anti-VGCC or anti-VGKC are clinically most relevant markers, but they are not specifically associated with a paraneoplastic etiology. Depending on the neurological syndromes, anti-neuronal antibodies must be supplemented by other diagnostic tests such as MRI, CSF, or electrophysiology. Combining these diagnostic options may lead to a sensitivity of close to $100 \%$ for detecting a paraneoplastic etiology [6].

\section{Anti-Hu Antibody}

Since the initial description of anti-Hu, this first clinically fully characterized paraneoplastic antibody has also turned out to be the most frequent $[3,8,22-24]$. The anti-Hu antibody may be associated with a central encephalomyelitis or a peripheral neuropathy. Importantly, the associated tumors tend to be limited and show no metastases (other than to mediastinal lymph nodes) [25]. Anti-Hu (at low titer) is also present in about $16 \%$ of patients with SCLC without neurological symptoms [26]. In these patients, the anti-Hu is a positive predictor of complete response to tumor treatment [27].

Anti-Yo Antibody

Anti-Yo defines a subgroup of patients with PCD and breast or ovarian cancer (see above) and is the second most common anti-neuronal reactivity $[11,12]$. One of the antigens recognized by anti-Yo sera is cdr2 (cerebellar degeneration-related protein) which is mainly expressed in cerebellar Purkinje cells and some tumors.

\section{Anti-Ma/Ta Antibody}

This antibody reactivity has only been recognized recently [5, $9,28]$. The antibody reactivity to Ma proteins is highly specific for a paraneoplastic etiology, and all patients react against the immunodominant Ma2 protein. In an isolated anti-Ma2 reactivity, patients tend to be younger and mainly have PLE associated with a germ cell tumor of testis. A reactivity against other Ma proteins (PNMA1, PNMA3) in addition to Ma2 identifies patients who are older, have a rhombencephalitis and PCD associated with several different tumors [5, 9, 28]. The function of the Ma proteins is still unknown.

\section{Anti-Tr Antibody}

Named after the first descriptor Trotter rather than an index patient [29], anti-Tr is found in PCD associated with Hodgkin's disease and reacts with cytoplasm of Purkinje cells additionally showing a characteristic punctate pattern in the molecular layer of the cerebellum $[30,31]$. Most patients recognize a myc-associated zink finger protein that it is not the $\mathrm{Tr}$ antigen [32]. Typically and in contrast to other paraneoplastic antibodies, the titer may turn negative during course of treatment and may only be found in CSF and not in serum [31,33]. Anti-CV2 Antibody / Anti-CRMP5 Antibody

Initially Honnorat et al. described anti-CV2 as a paraneoplastic marker in 1996 [34]. Recently, the group of Lennon described an anti-CRMP5 reactivity in 116 patients which probably constitutes the same antibody [35]. In the series of Yu et al. [35], 26\% had cerebellar ataxia, 25\% dementia, 17\% cranial neuropathy, $11 \%$ chorea, $10 \%$ loss of taste or olfaction, and $7 \%$ optic neuropathy. In $77 \%$ a lung tumor and in $6 \%$ a thymoma had been identified.

\section{Treatment}

Treatment options include tumor therapy, symptomatic treatment, and modulation of the immune system.

\section{Tumor Therapy}

In patients without known tumor but a highly likely paraneoplastic etiology finding the tumor is essential but may be difficult. As there is a biologically effective immune response against the underlying tumors, the tumors may initially stay locally or even histologically small [27]. If specific antibody reactivities are present, they direct the tumor search to specific organs. If a tumor is identified which does not fit the known tumor pattern, this tumor should be checked for 'atypical' expression of the relevant antigen [8], and the possibility of a second malignancy must be considered [23]. Recently, the use of whole-body FDG-PET has been advocated for early tumor diagnosis in patients with anti-Hu or clinically suspected PND [36-38]. With all therapeutic approaches in PND it must be kept in mind that the natural course may be fluctuating [5] or indolent [39] and that there may be spontaneous improvement of neurological symptoms [40], or even spontaneous tumor regression $[41,42]$. Some PND presentations such as SN or PLE tend to react better to therapy than others, such as PCD $[6,8$, 43]. For the majority of PND of the CNS, however, therapy is difficult, and must be started early. Tumor therapy is the mainstay of therapy, and a complete response to tumor therapy shows a favorable influence on the course of PND [44].

\section{Immunomodulatory Therapy}

Because of current evidence of an autoimmune pathogenesis, immunomodulatory treatment seems indicated in patients with paraneoplastic neurological syndromes, although studies with a high degree of evidence are lacking due to the low number of patients $[1,2]$. However, not all paraneoplastic syndromes respond well to the immunomodulatory options available so far. For some syndromes, immunomodulatory therapy rests on sound clinical evidence for its efficacy, such as GBS, CIDP, LEMS, or stiff-man syndrome.

For the remainder of syndromes - especially of the central nervous system -, all immunomodultory approaches used so far do not seem to be very effective on the whole, but may bring dramatic improvement in single patients. Improvement 
is more likely in PLE or paraneoplastic neuropathy $[6,8,38]$. In general, the earlier immunotherapy is started the better are the chances of improvement $[45,46]$. As immunomodulatory treatment options protein A absorption, ivIg, cyclophosphamide, or plasma exchange have been tried [1, 2, 47, 48]. Due to the uncertain effect, we would start with one course of i.v. methylprednisolone, such as in MS $(5 \times 500 \mathrm{mg}$ i.v. $)$, and wait for a possible effect for one or two weeks. If no effect is seen we would proceed to one course of ivIg (e.g. $2 \mathrm{~g} / \mathrm{kg}$ body weight distributed over 5 days), wait again for a possible effect, and if no effect is seen maybe proceed to plasma exchange or cyclophosphamide according to the individual patient's situation.

\section{Concluding Remark}

Paraneoplastic neurological syndromes may present with a varied clinical picture and must be included in nearly any neurological differential diagnosis. As a very helpful tool an ever growing battery of specific antibodies as paraneoplastic markers are available for the clinician. With increasing understanding of the autoimmune pathogenesis of these disorders, effective treatment options besides the oncological therapy may become available to the patients soon.

\section{Acknowledgement}

Our work is supported by Hermann und Lilly Schilling Stiftung, Wilhelm Sander Stiftung, Deutsche Krebshilfe and Deutsche Forschungsgemeinschaft.

\section{References}

1 Darnell RB, Posner JB: Paraneoplastic syndromes involving the nervous system. N Engl J Med 2003; 349:1543-1554.

2 Voltz R: Paraneoplastic neurological syndromes: An update on diagnosis, pathogenesis, and therapy. Lancet Neurol 2002;1:294-305.

3 Graus F, Cordon-Cardo C, Posner JB: Neuronal antinuclear antibody in sensory neuronopathy from lung cancer. Neurology 1985;35:538-543.

4 Graus F, Bonaventura I, Uchuya M, Valls-Sole J, Rene R, Leger JM, Tolosa E, Delattre JY:Indolent anti-Hu-associated paraneoplastic sensory neuropathy. Neurology 1994;44:2258-2261

5 Voltz R, Gultekin SH, Rosenfeld MR, Gerstner E, Eichen J, Posner JB, Dalmau J: A serologic marker of paraneoplastic limbic and brain-stem encephalitis in patients with testicular cancer. N Engl J Med 1999;340:1788-1795

6 Gultekin SH, Rosenfeld MR, Voltz R, Eichen J, Posner JB, Dalmau J: Paraneoplastic limbic encephalitis: Neurological symptoms, immunological findings and tumour association in 50 patients. Brain 2000;123(Pt 7):1481-1494

7 Condom E, Vidal A, Rota R, Graus F, Dalmau J, Ferrer I: Paraneoplastic intestinal pseudo-obstruction associated with high titres of $\mathrm{Hu}$ autoantibodies. Virchows Arch A Pathol Anat Histopathol 1993;423:507-511.

8 Graus F, Keime-Guibert F, Rene R, Benyahia B, Ribalta T, Ascaso C, Escaramis G, Delattre JY: Anti-Hu-associated paraneoplastic encephalomyelitis: Analysis of 200 patients. Brain 2001 Jun;124 (Pt 6):1138-48

9 Rosenfeld MR, Eichen JG, Wade DF, Posner JB, Dalmau J: Molecular and clinical diversity in paraneoplastic immunity to Ma proteins. Ann Neurol 2001;50:339-348

10 Posner JB: Paraneoplastic syndromes; in Posner JB (ed): Neurologic Complications of Cancer. Contemporary Neurological Series. Philadelphia, PA, FA Davis, 1995, pp 353-385.

11 Rojas I, Graus F, Keime-Guibert F, Rene R, Delattre JY, Ramon JM, Dalmau J, Posner JB: Longterm clinical outcome of paraneoplastic cerebellar degeneration and anti-Yo antibodies. Neurology 2000;55:713-715

12 Shams'ili S, Grefkens J, de Leeuw B, van den Bent M, Hooijkaas H, van der Holt B, Vecht C, Sillevis Smitt P: Paraneoplastic cerebellar degeneration associated with antineuronal antibodies: Analysis of 50 patients. Brain 2003;126(Pt 6):1409-1418.
13 Mason WP, Graus F, Lang B, Honnorat J, Delattre JY, Valldeoriola F, Antoine JC, Rosenblum MK, Rosenfeld MR, Newsom-Davis J, Posner JB, Dalmau J: Small-cell lung cancer, paraneoplastic cerebellar degeneration and the Lambert-Eaton myasthenic syndrome. Brain 1997;120(Pt 8):1279_ 12300 .

14 Graus F, Lang B, Pozo-Rosich P, Saiz A, Casamitjana R, Vincent A: P/Q type calcium-channel antibodies in paraneoplastic cerebellar degeneration with lung cancer. Neurology 2002;59:764-766.

15 Denny-Brown D: Primary sensory neuropathy with muscular changes associated with carcinoma. J Neurol Neurosurg Psychiatr 1948;11:73-87.

16 Molinuevo JL, Graus F, Serrano C, Rene R, Guerrero A, Illa I: Utility of anti-Hu antibodies in the diagnosis of paraneoplastic sensory neuropathy. Ann Neurol 1998;44:976-980.

17 Newsom-Davis J: Lambert-Eaton Myasthenic Syndrome. Curr Treat Options Neurol 2001;3:127-131.

18 Maddison P, Newsom-Davis J, Mills KR, Souhami RL: Favourable prognosis in Lambert-Eaton myasthenic syndrome and small-cell lung carcinoma. Lancet 1999;353:117-118.

19 Elrington GM, Murray NM, Spiro SG, NewsomDavis J: Neurological paraneoplastic syndromes in patients with small cell lung cancer. A prospective survey of 150 patients. J Neurol Neurosurg Psychiatry 1991;54:764-767.

20 Bain PG, Motomura M, Newsom-Davis J, Misbah SA, Chapel HM, Lee ML, Vincent A, Lang B: Effects of intravenous immunoglobulin on muscle weakness and calcium-channel autoantibodies in the Lambert-Eaton myasthenic syndrome. Neurology 1996;47:678-683.

21 Voltz R, Carpentier AF, Rosenfeld MR, Posner JB, Dalmau J: P/Q-type voltage-gated calcium channel antibodies in paraneoplastic disorders of the central nervous system. Muscle Nerve 1999;22:119-122.

22 Dalmau J, Graus F, Rosenblum MK, Posner JB: Anti-Hu-associated paraneoplastic encephalomyelitis/sensory neuronopathy. A clinical study of 71 patients. Medicine (Baltimore) 1992;71:59-72.

23 Lucchinetti CF, Kimmel DW, Lennon VA: Paraneoplastic and oncologic profiles of patients seropositive for type 1 antineuronal nuclear autoantibodies. Neurology 1998;50:652-657.

24 Sillevis Smitt P, Grefkens J, de Leeuw B, van den Bent M, van Putten W, Hooijkaas H, Vecht C: Survival and outcome in 73 anti-Hu positive patients with paraneoplastic encephalomyelitis/sensory neuronopathy. J Neurol 2002;249:745-753.
25 Verschuuren JJ, Perquin M, ten Velde G, De Baets M, Vriesman PB, Twijnstra A: Anti-Hu antibody titre and brain metastases before and after treatment for small cell lung cancer. J Neurol Neurosurg Psychiatry 1999;67:353-357.

26 Dalmau J, Furneaux HM, Gralla RJ, Kris MG, Posner JB: Detection of the anti-Hu antibody in the serum of patients with small cell lung cancer - a quantitative western blot analysis. Ann Neurol 1990;27:544-552.

27 Graus F, Dalmou J, Rene R, Tora M, Malats N, Verschuuren JJ, Cardenal F, Vinolas N, Garcia del Muro J, Vadell C, Mason WP, Rosell R, Posner JB, Real FX: Anti-Hu antibodies in patients with small-cell lung cancer: Association with complete response to therapy and improved survival. J Clin Oncol 1997;15:2866-2872.

28 Dalmau J, Gultekin SH, Voltz R, Hoard R, DesChamps T, Balmaceda C, Batchelor T, Gerstner E, Eichen J, Frennier J, Posner JB, Rosenfeld MR: Ma1, a novel neuron- and testis-specific protein, is recognized by the serum of patients with paraneoplastic neurological disorders. Brain 1999;122(Pt 1): 27-39.

29 Trotter JL, Hendin BA, Osterland CK: Cerebellar degeneration with Hodgkin disease. An immunological study. Arch Neurol 1976;33:660-661.

30 Graus F, Dalmau J, Valldeoriola F, Ferrer I, Rene R, Marin C, Vecht CJ, Arbizu T, Targa C, Moll JW: Immunological characterization of a neuronal antibody (anti-Tr) associated with paraneoplastic cerebellar degeneration and Hodgkin's disease. J Neuroimmunol 1997;74:55-61.

31 Bernal F, Shams'ili S, Rojas I, Sanchez-Valle R, Saiz A, Dalmau J, Honnorat J, Sillevis Smitt P, Graus F: Anti-Tr antibodies as markers of paraneoplastic cerebellar degeneration and Hodgkin's disease. Neurology 2003;60:230-234.

32 Bataller L, Wade DF, Graus F, Rosenfeld MR, Dalmau J: The MAZ protein is an autoantigen of Hodgkin's disease and paraneoplastic cerebellar dysfunction. Ann Neurol 2003:53:123-127.

33 Peltola J, Hietaharju A, Rantala I, Lehtinen T, Haapasalo H: A reversible neuronal antibody (anti-Tr) associated paraneoplastic cerebellar degeneration in Hodgkin's disease. Acta Neurol Scand 1998;98:360-363.

34 Honnorat J, Antoine JC, Derrington E, Aguera M, Belin MF: Antibodies to a subpopulation of glial cells and a $66 \mathrm{kDa}$ developmental protein in patients with paraneoplastic neurological syndromes. J Neurol Neurosurg Psychiatry 1996;61:270-278. 
35 Yu Z, Kryzer TJ, Griesmann GE, Kim K, Benarroch EE, Lennon VA: CRMP-5 neuronal autoantibody: Marker of lung cancer and thymoma-related autoimmunity. Ann Neurol 2001;49:146-154.

36 Antoine JC, Cinotti L, Tilikete C, Bouhour F, Camdessanche JP, Confavreux C, Vighetto A, Renault-Mannel V, Michel D, Honnorat J: [18F]fluorodeoxyglucose positron emission tomography in the diagnosis of cancer in patients with paraneoplastic neurological syndrome and anti-Hu antibodies. Ann Neurol 2000;48:105-108.

37 Rees JH, Hain SF, Johnson MR, Hughes RA, Costa DC, Ell PJ, Keir G, Rudge P: The role of [18F]fluoro-2-deoxyglucose-PET scanning in the diagnosis of paraneoplastic neurological disorders. Brain 2001;124(Pt 11):2223-2231.

38 Linke R, Schröder M, Helmberger T, Voltz R: Antibody-positive paraneoplastic neurological syndromes: The value of CT and FDG-PET imaging for tumor diagnosis. Neurology, in press.

39 Graus F, Bonaventura I, Uchuya M, Valls-Sole J, Rene R, Leger JM, Tolosa E, Delattre JY: Indolent anti-Hu-associated paraneoplastic sensory neuropathy. Neurology 1994;44:2258-2261.

40 Byrne T, Mason WP, Posner JB, Dalmau J: Spontaneous neurological improvement in anti-Hu associated encephalomyelitis. J Neurol Neurosurg Psychiatry 1997;62:276-278.

41 Darnell RB, DeAngelis LM: Regression of smallcell lung carcinoma in patients with paraneoplastic neuronal antibodies. Lancet 1993 2;341:21-22.

42 Gill S, Murray N, Dalmau J, Thiessen B: Paraneoplastic sensory neuronopathy and spontaneous regression of small cell lung cancer. Can J Neurol Sci 2003;30:269-271.

43 Suzuki M, Kimura H, Tachibana I, Fujimura H, Nakatsuji Y, Sugai F, Naba I, Nakamori M, Morishita H, Arai T, Osaki T, Hayashi S: Improvement of anti-Hu-associated paraneoplastic sensory neuropathy after chemoradiotherapy in a small cell lung cancer patient. Intern Med 2001:40:1140-1143.

44 Keime-Guibert F, Graus F, Broet P, Rene R, Molinuevo JL, Ascaso C, Delattre JY: Clinical outcome of patients with anti-Hu-associated encephalomyelitis after treatment of the tumor. Neurology 1999;53:1719-1723.

45 Blaes F, Strittmatter M, Merkelbach S, Jost V, Klotz M, Schimrigk K, Hamann GF: Intravenous immunoglobulins in the therapy of paraneoplastic neurological disorders. J Neurol 1999;246:299-303.

46 Keime-Guibert F, Graus F, Fleury A, Rene R, Honnorat J, Broet P, Delattre JY: Treatment of paraneoplastic neurological syndromes with antineuronal antibodies (Anti-Hu, anti-Yo) with a combination of immunoglobulins, cyclophosphamide, and methylprednisolone. J Neurol Neurosurg Psychiatry 2000;68:479-482.

47 Graus F, Vega F, Delattre JY, Bonaventura I, Rene R, Arbaiza D, Tolosa E: Plasmapheresis and antineoplastic treatment in CNS paraneoplastic syndromes with antineuronal autoantibodies. Neurology 1992;42(3 Pt 1):536-540.

48 Uchuya M, Graus F, Vega F, Rene R, Delattre JY: Intravenous immunoglobulin treatment in paraneoplastic neurological syndromes with antineuronal autoantibodies. J Neurol Neurosurg Psychiatry 1996;60:388-392. 